"The vulnerabilities of the residents of Baddawi camp are caused by political failures that have deep historical roots."

\title{
Refugees' Pandemic Responses in a Palestinian Camp in Lebanon
}

\author{
ElENA FIDDIAN-QASMIYEH AND YOUSIF M. QASMIYEH
}

$\mathrm{F}$ ar from being passive recipients of humanitarian aid, people who have experienced conflict and displacement are always finding ways to respond to the challenges they face and help others in the same situations. Since 2016, with a team of researchers in Lebanon, Jordan, and Turkey, as well as in Europe, we have explored how local communities in the Middle East have responded to displacement from Syria since 2011. We started from the premise that the members of such communities hosting refugees have often experienced displacement and forced migration in the past themselves, and may well face displacement again in the future. People who are currently labeled as refugees were, are, and will be hosts.

In our interviews in the Hamra neighborhood of Beirut in 2017-18, for instance, our Syrian and Lebanese interlocutors alike recalled their personal and family histories of having hosted Lebanese people displaced during the 1975-90 Lebanese Civil War. One-third of our Lebanese interviewees in Hamra had hosted Lebanese citizens who had been internally displaced in 2006 during the Israeli war on Lebanon. And half of our Syrian interlocutors had hosted internally displaced people in Syria since the outbreak of conflict there in 2011.

In light of such complex histories and shifting roles among refugees and their hosts, analyses of

ELENA FIDDIAN-QASMIYEH is a professor of migration and refugee studies at University College London. YousiF M. QASMIYEH is a poet, translator, and doctoral student in literature at the University of Oxford. This essay is informed by two research projects-Refugee Hosts and Imagining Futures-funded by the UK's Arts and Humanities Research Council and the Economic and Social Research Council, and it expands on an article published in the Summer 2020 issue of the Journal of Palestine Studies. In memory of Mustafa (1943-2020). displacement should resist the presentist bias that prevails in much media reporting and policy rhetoric about forced migration. The ways that histories of displacement intersect with histories of hosting have important implications for both the present and the future. Solely focusing on-and providing aid to- "newly" displaced people can discriminate against those living in protracted situations of displacement, whose vulnerability may increase over time.

As the events of 2020 have starkly illustrated in Lebanon, vulnerabilities may be accentuated by intersecting crises such as the COVID-19 pandemic, which has afflicted the country since March, and the devastating explosion in Beirut's port on August 4, believed to have been caused by an impounded cargo of ammonium nitrate stored for several years in a warehouse without proper safety precautions. With a blast radius that extended up to 10 kilometers from the port, the explosion killed over 200 people, seriously injured more than 6,500 , left severe damage in more than half the city's neighborhoods, and rendered some 300,000 people homeless, including citizens, refugees, and migrants. It wiped out over 80 percent of the country's wheat reserves; demolished key infrastructure, including three hospitals and half of the city's clinics; and created major impediments for the emergency delivery of humanitarian aid supplies.

International donors sent aid, including medical supplies and equipment, to Lebanon via the smaller northern port of Tripoli. The Lebanese Red Cross headquarters subsequently announced that all of the group's hospital teams in the north would be relocated to Beirut due to a shift in priorities: they were needed to bolster medical capacity to assist both blast survivors and the dramatically increasing number of COVID-19 patients in the capital. 
It is to the coronavirus pandemic that we now turn, shifting from Beirut (which has been the focus of so much attention) to a small and under-researched urban refugee camp in North Lebanon called Baddawi camp. Here in Baddawi, residents have been supporting both "old" and "new" fellow refugees who share the camp amid the multifaceted risks created by the pandemic and by the diverse responses to it, from the allocation of health care resources to anti-refugee rhetoric. To provide more direct, personal impressions of what it is like to experience these conditions than can be conveyed by more detached analytical observations, we intersperse our reflections with excerpts from the poetry of one of the authors, Yousif M. Qasmiyeh—who was himself born in Baddawi camp.

\section{LIFE IN A CROWDED CAMP}

"What makes a camp a camp? And what is the beginning of a camp if there is any? And do camps exist in order to die or exist forever?" These questions, posed by Qasmiyeh in his 2016 poem "Writing the Camp: Writing the Camp Archive," hover as we consider how to introduce Baddawi camp. One way of doing so is as follows:

Baddawi camp is situated on the outskirts of Lebanon's second-largest city, Tripoli, near the small town of Baddawi, which is located on the coastal road that runs all the way to Syria. The camp was established in the mid-1950s to house Palestinian refugees. Ever since, it has remained on the original one-square-kilometer plot of land leased by the Lebanese state to the United Nations Relief and Works Agency for Palestine Refugees in the Near East (UNRWA). But it has expanded vertically to accommodate not only the original inhabitants and their families, but also the thousands of people who have arrived Baddawi from different conflict situations across Lebanon and farther afield. These included Palestinians from other Lebanese camps, like al-Nabatiyeh, destroyed by Israeli air raids in 1974; Tel el-Zaatar, razed to the ground in 1976 by Lebanese Christian militias and the Syrian army; and Nahr el-Bared, shelled and bombarded in 2007 by the Lebanese Army in clashes with the Fatah al-Islam militant group. The most recent arrivals are refugees from the ongoing Syrian conflict.
Alongside that conventional description, consider these excerpts from "Writing the Camp":

Baddawi is my home camp, a small camp compared to other Palestinian camps in Lebanon. For many residents, it comprises two subcamps: the lower and the upper camps that converge at the old cemetery. As I was growing up, it was common for children to know their midwife. Ours, perhaps one of only two in the entire camp, was an elderly woman, who died tragically when a wall collapsed on top of her fragile body during a stormy day in the camp. The midwife was the woman who cut our umbilical cords and washed us for the first time. She lived by the main mosque-Masjid al-Quds-that overlooked the cemetery. She would always wait by the cemetery to stop those who she delivered en route to school, to give them a kiss and remind them that she was the one who made them.

The camp is never the same albeit with roughly the same area. New faces, new dialects, narrower alleys, newly-constructed and ever-expanding thresholds and doorsteps, intertwined clothing lines and electrical cables, well-shielded balconies, little oxygen, and impenetrable silences are all amassed in this space....

Refugees ask other refugees, who are we to come to you and who are you to come to us? Nobody answers. Palestinians, Syrians, Iraqis, Kurds share the camp, the samedifferent camp, the camp of a camp. They have all come to re-originate the beginning with their own hands and feet.

These processes of different groups of displaced people "re-originating the beginning" reflect the extent to which the camp is always in a state of becoming, due to overlapping forms of conflict and displacement. Refugees create and recreate the camp, as well as knowledge of the camp.

\section{DISCRIMINATION AND DISTRUST}

Focusing on the responses developed by and for both Palestinian and non-Palestinian residents in Baddawi camp highlights the importance of relationality. In this context, the term encompasses relationships among different groups of refugees, including Palestinians and Syrians, as well as the intersections of local-level responses with local, national, and international structures of inequality, exclusion, and marginalization. 
Palestinians in Lebanon have historically been denied access to key rights and state services, including citizenship and health care. Both of the UN's refugee agencies, UNRWA and the office of the UN High Commissioner for Refugees (UNHCR), currently operate in Lebanon's Palestinian camps. These camps have been home to Palestinians since the 1950s. Since 2011, they have also been hosting refugees from Syria.

UNRWA is ostensibly responsible for the wellbeing of Palestinian refugees, whereas UNHCR has a mandate to protect all non-Palestinian refugees. One might assume that the presence of these two UN agencies means that refugees in Palestinian camps have access to two sets of support systems. With their widely divergent budgets, mandates, and programmatic activities, however, the UN agencies have created a bifurcated system of assistance, consolidating a hierarchy of worth and exclusion among different groups of refugees on the basis of their nationalities and places of origin. Even in the midst of the pandemic, the two agencies have largely failed to cooperate in their efforts to support displaced people living side by side.

As the number of COVID-19 cases has risen across Lebanon, to around 37,300 by the end of September 2020, according to the official count (though there are fears that cases have been dramatically underreported), so, too, have xenophobic, antirefugee, and discriminatory responses. Mobilizing the well-worn trope that refugees are spreaders of disease, Lebanese officials and politicians at the start of the outbreak promptly demanded that $\mathrm{Pa}$ lestinian camps be placed under even greater control and surveillance, invoking the threats that have long been imagined as emanating from these "foreign" and "polluted" spaces.

Although coronavirus infections in Lebanon reportedly originated among Lebanese nationals (mainly religious pilgrims returning from countries such as Iran and Italy), such demands resulted in the camps being placed under tight lockdowns in early March. Local municipalities discriminated against Palestinian and Syrian refugees alike, imposing long curfews that were not extended to either Lebanese citizens or nonLebanese residents in other areas, and forcibly preventing people from leaving their home camps. In March, the Lebanese Red Cross reportedly refused to transfer a refugee camp resident with a suspected case of COVID-19 to Rafik Hariri University Hospital in Beirut, the only public hospital where coronavirus patients were being quarantined and treated free of charge. This caused great alarm inside the camps.

Camp residents in Lebanon-including Palestinians, Syrians, Iraqis, Kurds, and Lebanese-are acutely vulnerable to the impacts, of COVID-19. (Lebanese residents include people who have intermarried, some who are drawn by the cheaper rents or even the prospect of a free burial in the camp's cemetery, and others who work in the camps with other residents.) Living in overcrowded urban camps with poor infrastructure, many are afflicted with preexisting health conditions that have multiplied and worsened. The fragile UNRWA health systems have been defunded and weakened over decades by fickle donors, while Lebanese health systems have a long history of discriminating against and denying treatment to refugees.

Against this backdrop, it is not surprising that mistrust among Palestinians and their fellow camp dwellers toward international and national aid agencies and government departments has remained high as they have faced COVID-19. Yet refugees in Lebanon, like other displaced and dispossessed people around the world, have drawn on long-standing traditions of mutual aid and solidarity to seek ways to protect themselves and others from the pandemic.

\section{IMPROVISING SOLUTIONS}

As of mid-June 2020, only 12 COVID-19 cases had been confirmed among Palestinian refugees in Lebanon. But by the end of September, UNRWA reported that 963 Palestinians had tested positive, of whom 24 had died. How have the residents of Baddawi camp responded to this impending catastrophe?

As we wait for the disease, in echoless rooms, doors locked up, shutters dusted, thrust to the heart.... The disease that will sign a pact with our diseases. In patience bereft of patience, we stand still behind our walls: without seeing, we shall see the disease that will be....

With a third eye, I see the catastrophe.

On March 22, camp organizations including the Security Committee (a coalition of Palestinian factions that at times acts as a mediator with UNRWA and Lebanese officials to maintain security in the camps) announced a curfew for the camp's residents and businesses. Unlike previous curfews and 
camp lockdowns (there have been many since the camp was established in the 1950s), this one was not imposed by Lebanese authorities asserting that the camps posed a danger to the surrounding communities. Instead, after COVID-19 cases were confirmed in a neighboring area outside the camp, refugee activists lobbied for the camp's entry points and exits to be closed in order to protect its residents.

In Lebanon, as in other displacement and hosting contexts, refugee camps are not isolated spaces. They are intimately connected to urban and non-urban areas beyond the camp limits. Palestinian camps have often been perceived as "islands of insecurity" (to use anthropologist Rosemary Sayigh's words), but when the pandemic arrived, many camp residents promptly identified the risks existing outside the camp and encouraged fellow inhabitants to remain inside.

Since before the curfew started, many advocates and volunteers in Baddawi camp have been working tirelessly to prepare and distribute information, guidelines, and resources to help keep residents as safe as possible during this pandemic. They have developed inclusive approaches designed to reach all residents, irrespective of nationality or legal status.

UNRWA was perceived as having been slow to inform camp residents about the risks of COVID-19 and provide support. So members of the Palestinian Cultural Club in Baddawi camp promptly took action, drawing on their intimate knowledge of everyday life and needs in the camp. They adapted existing evidence-based informational posters (including World Health Organization materials), translated them into Arabic, and shared the posters and other forms of guidance in print and via social media to reach camp residents of all demographics in an accessible manner.

In addition to running special programs on its radio station, the Cultural Club has worked with social media networks that have been established locally for years. These networks previously had been used to inform residents about everything from school closures to which areas of the camp should be avoided during armed clashes or sporadic shootings. While the threat of COVID-19 is less visible, or audible, the threat to life is no less real, and information is among a range of resources essential for survival in these circumstances.

Food is another essential resource, of course, and camp residents try to make sure everyone receives enough. Over the past few years, in preparation for the holy month of Ramadan, Palestinian residents-including members of the Cultural Club-have collected financial donations from other Palestinians to prepare iftar food baskets for distribution to residents identified as especially in need, whatever their nationality (Palestinian, Syrian, Iraqi, Kurdish, or Lebanese) or place of origin. In 2020, given the fears and restrictions on movement due to the pandemic, the organizers were concerned that it would not be safe for large numbers of people to go door to door collecting donations or to work together shopping for ingredients, cooking, and distributing hot meals during Ramadan.

The disease is not yet here. Alongside our heavy hearts, we have what will be: flour, beads of yeast, whole and crushed lentils, potatoes, their red soil to nurture escaping blessings in dryness.

The number of people in need of food in the camp has been much larger than in previous years-not just because of the pandemic, but also due to the ongoing collapse of the already fragile Lebanese economy. As an acute financial crisis has spiraled since 2019, people who were lucky enough to receive salaries through bank transfers have been unable to withdraw money from their bank accounts for months. Dollar withdrawals from banks were suspended on March 30 amid a national liquidity shortage.

Camp residents who once relied on remittances from family and friends abroad have been unable to receive international money transfers. The closure of the Beirut airport and the country's land borders has made it nearly impossible for relatives to send cash directly. The devaluation of the Lebanese lira compounded a more than two- or even threefold rise in prices for basic necessities over the course of only a few months.

With cash scarce and movement restricted in the camp, the Cultural Club started seeking other ways to safely collect and distribute donations to people in need. Club members contacted local businesses, including groceries and mini-markets both inside and on the outskirts of the camp, 
soliciting cash and in-kind donations. The club also produced and broadcast a "Who Will Donate a Million?" fund-raising drive on its online channel.

As donations were secured, the club's facilitythe ground-floor unit in an old apartment block in the camp, comprising three small rooms and a small patio-was converted into a storage and packing unit. Having initially considered that distributing tinned food items so that people could cook their own iftar meals would be the safest option, the club members soon realized that many residents were unable to afford cooking gas, or might lack cooking or refrigeration appliances. They decided to maintain the original plan of working together, as safely as possible, to cook hot meals for distribution to camp residents breaking the daily fast during Ramadan.

Just a few days before the start of Ramadan on April 23, as the limits of local resources became increasingly apparent, the Cultural Club's chapters in Baddawi and Mar Elias camps joined an emergency relief fund-raiser in partnership with al-Naqab Center (a youth-based cultural group) in Burj al-Barajneh camp and two us-based Palestinian initiatives, the Palestinian Youth Movement and Al-Awda: The Palestine Right to Return Coalition. The aim was to raise $\$ 50,000$ to buy and distribute packages of food and sanitizing products (each worth approximately $\$ 50$ ) to help the residents of those three camps practice social distancing and offset some of the economic damage caused by the pandemic. Within three months, the initiative had exceeded that goal.

\section{SYRIAN SCAPEGOATS}

For communities living in poverty around the world, the risk of contracting COVID-19 is paralleled, or surpassed, by the risks of destitution and starvation arising from policies and political decisions. Social distancing is ultimately impossible among people who live in overcrowded conditions, who have no savings to draw on to buy food, and whose survival is contingent on precarious daily labor in the informal sector.

In Lebanon, national authorities have long prohibited Palestinian and Syrian refugees from entering the formal labor market. That leaves them among the people least likely to be able to afford to practice social distancing, putting them at higher risk of contracting the virus.

Local initiatives have sought to help make people more capable of social distancing. But national policies and politics in Lebanon have created structures of inequality and exclusion over decades. In the first half of 2020 , national and municipal authorities created new forms of marginalization and discrimination with COVID-19 testing programs that targeted people on the basis of nationality.

On June 21, when there were still relatively few confirmed COVID-19 cases among Palestinians and Syrians in Lebanon (12 and 13 cases, respectively), municipal authorities and the state-run National News Agency reported that Syrian refugees working in Tripoli's port and living in Baddawi camp and on its outskirts in Wadi al-Nahleh had tested positive for the virus. In a flurry of public announcements, one by the UNRWA Health Department warned that these confirmed cases marked a tipping point in the country: "The epidemic no longer just threatens our camps-it has now entered them." Random tests on 119 Palestinian residents in June had all been negative; UNRWA officials implicitly asserted that the previously "clean" camp was now at risk due to the Syrians' infections.

UNHCR, the UN agency ostensibly responsible for Syrian refugees, has been conspicuous by its absence both inside and outside Baddawi camp. Our interviews with camp residents confirmed that these Syrians and their families received food supplies from UNICEF to sustain them under quarantine. They had received no assistance from UNHCR.

Local actors in the camp, including its Palestinian factions and its Popular Committee, announced that they had identified the location of the two Syrians' living quarters, marking them as the epicenter of contagion risk in the camp. Contact tracing was immediately set in motion under the supervision of the camp's Health Committee and the Lebanese Ministry of Health, which had committed to transferring any individuals who tested positive to a state hospital. As these developments unfolded, some camp residents started to associate COVID-19 with Syrians, in line with xenophobic rhetoric used by Lebanese politicians at the onset of the pandemic.

Amid rising fear over the arrival of the virus, members of the Popular and Security committees roamed through the alleyways and streets of the camp, instructing people to shutter their shops and stay indoors. Baddawi camp was once again subjected to closure, a space and community in quarantine. 


\section{A BORROWED AMBULANCE}

Since the devastating August 2020 blast in Beirut's port, coronavirus infection rates have soared across Lebanon, and medical infrastructure nationwide has been under mounting pressure. All of the Red Cross hospitals in north Lebanon are relocating, with medical staff either being laid off or moving to Beirut in order to care for both blast survivors and the rising number of COVID-19 cases in the capital.

While the focus on Beirut is understandable, given the vast destruction caused by the port explosion, allocating more resources to the capital puts people living elsewhere in the country at greater risk, citizens and refugees alike. UNHCR has been working to expand hospital capacity for COVID-19 patients (regardless of their nationality), adding 16 intensive care units (ICUs) in Halba's Governmental Hospital, in the northern Akkar municipality; Rafik al-Hariri Hospital in Beirut; and Saida's Governmental Hospital in South Lebanon. At the time of this writing, however, no additional ICUs are yet available in the government hospital in Tripoli, which is the nearest hospital to Baddawi camp.

Recognizing the increasing pressure on medical infrastructure amid the national emergency, as infection rates and deaths started to increase in Baddawi camp, the Cultural Club approached local officials in the town of Baddawi in August to ask if it could use one of the municipality's ambulances to take refugees with COVID symptoms to hospitals. The municipality granted its approval, loaning the club an ambulance that was not being used.

A member of the club volunteered to collect people with suspected COVID-19 infections from both Baddawi camp and the neighboring camp, Nahr el-Bared, and transport them to hospitals in Tripoli and Halba, and in some cases to Rafiq al-Hariri Hospital in Beirut. This refugee-driver wears a hazmat suit and protective gear provided by the Red Cross and Red Crescent Society at the club's request. Masks are bought from local supermarkets and shops in the camp and neighboring areas.

By "borrowing" the ambulance, the Cultural Club is using the citizen's tools to assist other refugees, improvising with the limited available resources to navigate entrenched inequitable systems. Such makeshift measures, however, are not sustainable, and they are no substitute for the health care resources that local and national governments should be allocating to the camps during this crisis to protect both their residents and the surrounding communities.

\section{STRIVING FOR SOLIDARITY}

Local responses developed by Baddawi camp residents demonstrate the ways in which refugees have worked individually and collectively to find means of caring for Palestinian, Syrian, Iraqi, Kurdish, and Lebanese residents in highly precarious conditions, at a time when their vulnerability is only increasing. These kinds of refugee-led crisis responses have long transcended nationalitybased identity markers. But over the past few months, such modes of solidarity and mutuality have had to contend with national and municipal interventions that align with policies and political discourses constituting refugees as the Other-as the threatening carrier of disease and risk. In this context, political pressures and responses can sometimes divide camp residents along national lines.

Such hostile rhetoric ignores the fact that refugees are often hosts to other refugees, and take responsibility for their well-being when the state fails to do so. Recognizing the many roles that they play to protect members of their own communities, and others, is an essential means of challenging monolithic representations of refugees as either security threats or passive recipients of international aid. Documenting and archiving such local responses is necessary to record how refugees seek to fill gaps and redress inequalities that have been created and reproduced by national and international actors alike.

Well before the COVID-19 pandemic, mutual aid initiatives in Baddawi camp provided support to residents with wide-ranging backgrounds. It is important to critically examine how such preexisting support systems and networks are coping with both the pandemic itself and the different policies and politics emerging in response to the crisis.

We cannot understand either the vulnerabilities that people face in displacement or the responses they develop without considering the ways that local experiences are framed by systems on multiple scales, including long-entrenched structural inequalities and processes of marginalization and exclusion. The vulnerabilities of the residents of 
Baddawi camp are caused by political failures that have deep historical roots. As these refugee communities, isolated by the authorities, turn to each other for help to survive crisis after crisis, the repercussions will continue to be felt in both the near and distant future.
When the camp falls ill, tomorrow falls ill for its sins.

By tomorrow, by its disavowed promise, we promise the disease what we have of wishes: a camp big enough for death, a camp with fewer deaths. 